\title{
THE SKULL BONES OF THE Iguana iguana
}

\author{
OSSOS DO CRÂNIO DO Iguana iguana
}

\author{
Rozana Cristina ARANTES', Maria de Jesus Veloso SOARES', Ana Kelen Felipe LIMA ${ }^{1}$, \\ Frederico Ozanan CARNEIRO E SILVA², Angelita das Graças Honorato de OLIVEIRA ${ }^{2}$ \\ 1. Course of Veterinary Medicine of Veterinarian Medical College of Tocantins Federal University of Campus Araguaína, TO, Brazil. \\ rozanacristina.arantes@gmail.com; 2. Course of Veterinary Medicine of Veterinarian Medical College, Federal University of \\ Uberlândia, Uberlândia, MG, Brazil
}

\begin{abstract}
The iguanas (Iguana iguana) are animals that can reach up $110 \mathrm{~cm}$. The crest of spines that is located at the its back long characterizes these animals. They live from Mexico to Central Brazil, in the Amazon, Cerrado, and Caatinga, they live in trees and have daytime habits and are herbivorous. This group habits all regions, except the polars regions. The objective was the description of the skull of bones of a representative of this specie. The members of this group live in all regions, except the Polar Regions. The objective of this research was to give a description of the skull bones of this specie. The Companhia Independente de Polícia Rodoviária e Ambiental do Estado do Tocantins (CIPRA) gave to the Veterinary Anatomy Laboratory of the Veterinarian Medical College, of the Tocantins Federal University, Campus of Araguaína, a specie the animal, after the animal be killed by a trauma. The animal's body was macerate by the technique of cooking. The skull was separate from the body, and following was accomplished the description of the skull bones. The following bones form the Iguana skull: premaxillary, nasal, prefrontal, frontal, prefrontal, parietal, jaw, lachrymal, jugal, postorbital, squamosal, ectopterygoid, epipterigoide, pterygoid, prootic quadrate bone, jaw, vomer, palatine, parasphenoid rostral, parasphenoid rostral, parabasisphenoid, supratemporal, exoccipital-opisthotic, supraoccipital. The iguana skull bones present similarity to the skull bones of the others representatives of the reptiles.
\end{abstract}

KEYWORDS: Anatomy. Wild Animals. Description. Iguanidae. Reptiles.

\section{INTRODUCTION}

Reptiles conquered the terrestrial environment, after acquiring the ability to avoid dehydration, internal fertilization. This group covers all habitats except the Polar Regions. It is divide in four orders: Chelonian, which includes turtles, terrapins and tortoises; Crocodilla, whose individuals are alligators and crocodiles; Rhincocephalia corresponding to tuatara and Squamate representes for two suborder: Ophidia and Lacertilia. There are about 3300 species of lizards. They inhabit different environments, swamps, deserts, beaches, mountains and they have arboreal or digger habits. Moreover, they are insectivorous or herbivorous, as well as the lizards can be oviparous, but some species are ovoviviparous. It has been estimate that $15-20 \%$ of all wild animals in world and largest number of endemic species globe live in Brazil (CUBAS et al., 2007). Iguana iguana is an animal that can reach up 110 centimeters in length. The crest of spines is a characteristic of these animals and runs the length of the back of the neck until the tail and the jowls, and they live in Amazon, Cerrado and Caatinga, from Mexico to Central Brazil, as well as they are arboreal, diurnal and herbivores (WIELOCH et al., 1997).

The researches about anatomy begin with knowledge the bones. Through osteology of the vertebrates it is possible determine phylogenetic lines, providing information relating to wild animals, which many theirs are risk imminent extinction. (HILDEBRAND; GOSLOW, 2006).

In face scarce anatomical literature regarding the iguanas, and large threat in relation to trafficking of animals and big interest as "exotic pet", it is essential the morphology study of these species. This research will help the clinic, surgery and reproduction of the iguanas. Moreover, this research had as objective to describe skull bones of Iguana iguana, comparing with others representatives this family.

\section{MATERIAL AND METHODS}

A male iguana (Iguana iguana) killed because of a trauma, and donated by the Companhia Independente de Polícia Rodoviária e Ambiental do Estado do Tocantins - CIPRA, in Araguaína Tocantins. The experiment was conducted in the Veterinary Anatomy Laboratory of the Veterinarian Medical College, of the Tocantins Federal University, Campus of Araguaína.

The animal was macerated by cooking technique. A ventral midline incision was realized for removal all skin, skin appendages, muscle, internal organs, nerves and blood vessels without damaging the bones. The animal was put to 
hydrogen peroxide solution of 20 volumes for 30 minutes, and then it disarticulated the skull, after held macroscopic description its bones. (RODRIGUES, 2010).

The identification and description of the skull according to Queiroz (1987). The photographic record was through of model Nikon L 120 camera 14.1 MP.

\section{RESULTS AND DISCUSSION}

The skull shape is important in the differentiation of species, the evolutionary scale, as well as specify the phylogeny of iguanes. In the the evolution, morphological changes in skull can be determined, specify the species of Brachylophus, Ctenosaura, Cyclura, Dipsosaurus, Iguana and Sauromalus (QUEIROZ, 1987).

Dorsal view observed bones premaxilla, nasal, prefrontal, frontal, parietal and postfrontal (Figure $1)$.

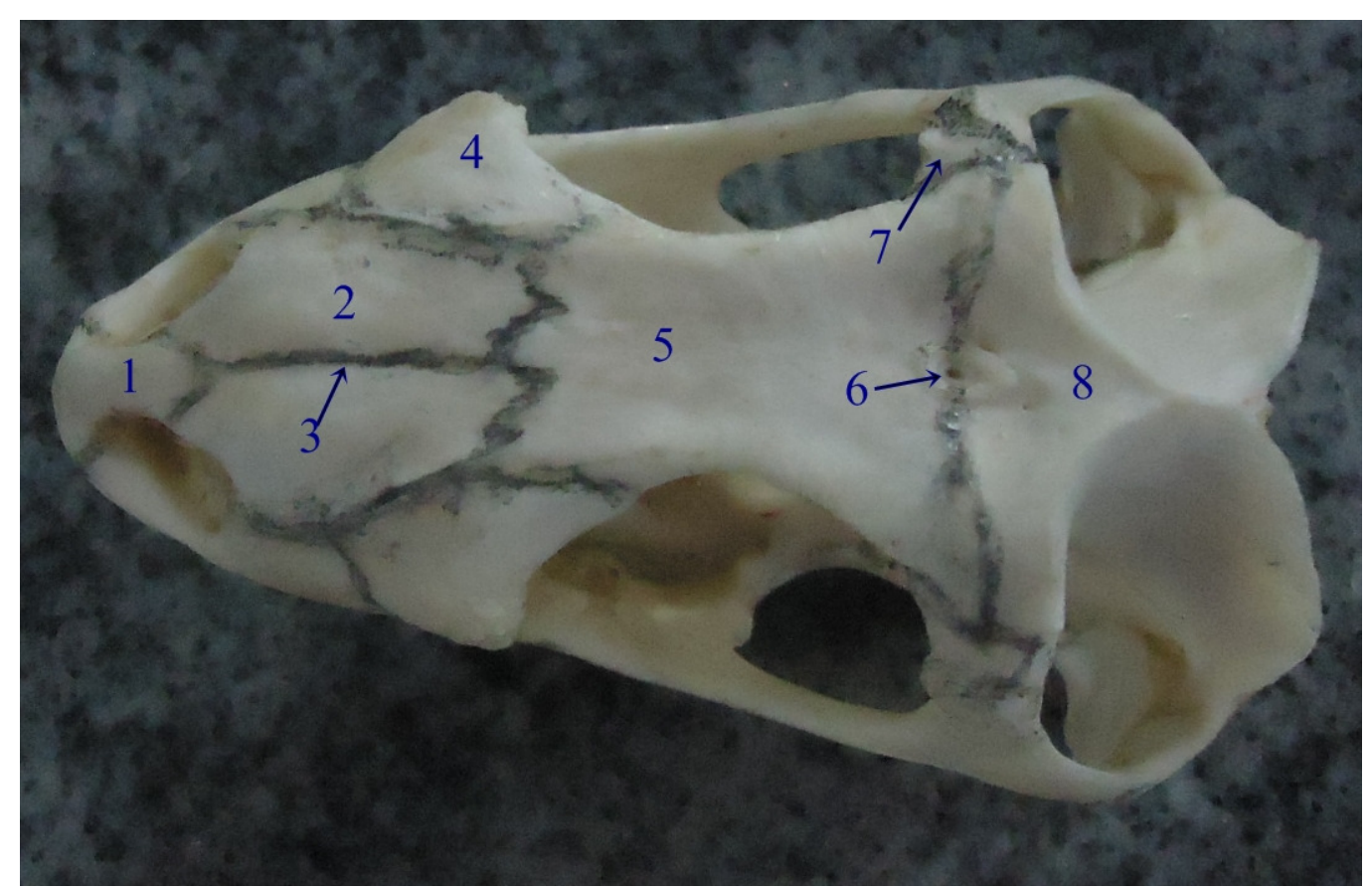

Figure 1. Dorsal view of the skull of Iguana iguana. 1-premaxillary, 2- nasal, 3-internasal suture, 4- prefrontal, 5-frontal, 6-parietal foramen, 7-postfrontal, 8-parietal.

Premaxilla (Figure 1:1) is single and median, rostral its base is wide and flat in its middle third, caudally is similar to a V shape, as well as it forms the medial wall of the nostrils. Six dental alveoli was observed. Premaxilla articulates laterally with maxillary, caudodorsally the nasal and caudoventrally with vomer bones. Incisor process localized the median region, delimits two cracks, called incisive and palate fissures. These findings were corroborated by Cope (1892), however be separate or fused in some representatives of the Squamate order (ESTES et al., 1988). Some contradictions were occurred with Wiliston (1925) noted, in small and aquatic reptiles pre-maxillary was originally elongated morphology, having eight or ten dental alveoli. The nasals (Figure1:2) are united level sagittal median plane, rostrally articulates premaxilla and prefrontal, laterally and caudally maxillary and frontal, respectivelly. Its morphology comparable a pyramid with an irregular basis, in addiction its forms the dorsocaudal wall nostrils. The findings this research contradict the descriptions of Estes et al. (1988), for in some representative Squamate order, rostrolaterally the nasal was separated the prefrontal for process of frontal bone. Cope (1892) mentions the nasal articulates with premaxillary and maxillary.

Prefrontal (Figure 1:4) are bones pairs that connect rostrally maxillary and nasal, laterally lacrimal and caudodorsally frontal. They participate in conformation dorsal, rostral and lateral bony orbit walls; it also has a prominent ridge on lateral side. The results this study were corroborated for Williston (1925), however, he mentioned prefrontals articulate with provomers in Chelonia and palatines and pterygoids in Crocodilia.

The frontal (Figure 1:5) is single, it has rostrally projections and it articulates, rostrodorsally with nasal and prefrontal, caudodorsally with parietal dorsalaterally postfrontal and 
ventralrostrally ethmoid. Its middle third is narrow, widens gradually caudally and it forms dorsal wall of bony orbit. In its dorsal face, noted parietal foramina, structure relates to pineal gland, which under the influence of photo period, interferes with this species breeding season, its localized on dorsal median line, in articulate with parietal (QUEIROZ, 1987; KARDONG, 2011). The resultant this research were also partially supported by Cope (1892); as well as Williston (1925). Cope (1892) mentions that the frontal was unique due to embryologies fusions, and he denominated the parietal foramen as pineal foramen, in reference to pineal gland. Williston (1925) observed, in some lizards, the frontal articulates with maxillary and parietal foramen was absent. The parietal (Fig. 1:8) is singular and irregular moreover it connects to rostrally frontal laterally postfrontal, postorbital and squamosal, caudally occipital and ventrally epipterygoid. The results for Iguana iguana agree with the observations of Williston (1925), for the Crocodilia Order parietal articulates with pterygoid. The postfrontals (Figure 1:7) are two small bones confined the posterior margins of bony orbits. Laterally, it has crest or knob bony, moreover it articulates with frontal, parietal and postorbital, respectively in laterally, medially, and caudally. Williston (1925) corroborated these sentences.

When correlated with Estes et al. (1988) percieved some differences because they report that the postfrontals can be fused with postorbitals, however they report that these bones had reduced dimensions in some families iguanes. Cope (1892) reports that, when present, the post-frontal bone was been reduced to supratemporal process.

In lateral view skull, observe the bones premaxillary, nasal, prefrontal, maxilla, prefrontal, frontal, lacrimal, jugal, postorbital, squamosal, ectopterygoid, epipterygoid, pterygoid, prootic, square (Figure 2).

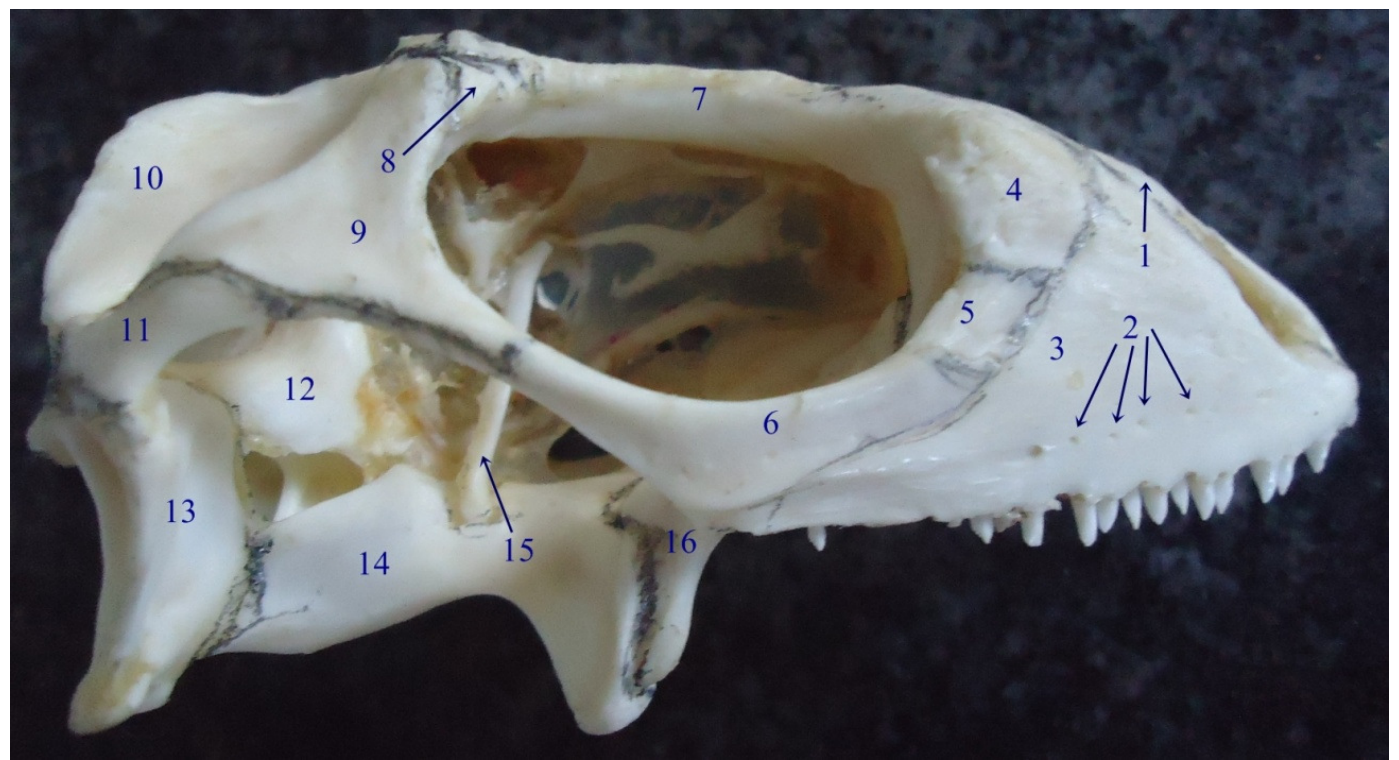

Figure 2. Lateral view skull Iguana iguana. 1-nasal, 2-supralabials foramina, 3-maxillary, 4-prefrontal, 5lacrimal, 6-jugal, 7-frontal, 8-postfrontal, 9-postorbital, 10- parietal, 11-squamosal, 12-prootic, 13square, 14-pterygoid, 15-epipterygoid, 16-ectopterygoid.

Maxillary (Figure 2:3) are pairs and have the joint cavities for teeth, (medial side) and seven supralabials foramina, of differents sizes, these foraminas formed ventral parallel line, on the ventral (lateral side). In its dorsal surface has a crest, which continues caudally prefrontal and its shape is triangular, articulating premaxilla, (rostolaterally), nasal and prefrontal (dorsocaudally), lacrimal (caudolaterally), jugal (caudolaterally), and pterygoid ventrally, and it form the ventrolateral wall of the nostril. The maxillary descriptions of Iguana iguana in conflict with the observations of Williston (1925), for Lacertilia, in the maxillary usually articulates the premaxillary, sometimes with the nasal, prefrontal, jugal, provomer, palatine and ectopterygoid. Estes et al. (1988) found in lizards' families, that the maxillary has dental alveoli. Cope (1892) reported that maxillary are articulated with premaxillary spine.

The lacrimals (Figure 2:5) are two small bones located in the lateral region of bony orbit; lacrimal foramen is medial, which is well developed. The findings this study were corroborated by Cope (1892), for Lacertilia suborder, and Estes et al. (1988) for Squamate order, mentioned that lacrimal can be present or 
fused to prefrontal and they also observed two lacrimal foramina.

The jugals (Figure 2:6) are pairs and it forms the lateral wall of bony orbit, in addiction they articulates with lacrimal (rostrodorsally), maxillary (rostroventrally), ectopterygoid (medially), postorbital (caudodorsally) and squamosal (caudally). Its median third is long and broad as the caudal portion is long and thin. These observations denote agreement with Williston (1925) reported that the involvement this bone in the formation of lateral orbital wall, but also according to the author in some lizards can be vestigial or absent, or fused to the square forming squarejugal. Estes et al. (1988) cited that jugal could fused to squamosal constituting jugosquamosal and some representatives Squamate order, the bony orbit is incomplete.

The postorbitals (Figure 2:9) articulate with jugal (ventrally), squamosal (ventrocaudally), postfrontal and parietal (dorsally). Its morphology that resembles a triangle and participate in formation of caudal wall bony orbit, these data also reported by Estes et al. (1988) for postorbital, in Squamate order. Williston (1925) cited postorbital articulate with parietal, as well as absent of intertemporal and supratemporal. , and Cope (1892) noted, when present, the postorbital is supratemporal process Squamosals are two irregular bones, moreover it forming also caudal wall of bony orbit, and it articulates with jugal (rostrally), square (ventrocaudally), postorbital (dorsocaudally). Williston (1925) and Estes et al. (1988) percieved that for Squamate order, squamosals can be vestigial or absent, respectively. Williston (1925) considered squamosal as a process of pterygoid.

The ectopterygoids (Figure 2:16) articulate with coronoid of mandible (ventrorostrally), maxillary (rostrodorsally), jugal (dorsally) and pterygoid (caudally) and its lateral wall formed suborbital foramen. The epipterygoids (Figure 2:15) have outline of thin rod and it articulates with pterygoid (ventral) and parietal (dorsal). Pterygoids (Figure 2:14) are pairs that form the wall bony caudal palate. It feature a serrated crest in its middle third, the piriform recess, and three processes: palate (rostral), transverse (rostrolateral) and square (caudal), in addiction they form the caudomedial wall of suborbital foramen and it articulates with palatine (rostrally), ectopterygoid (laterally), epipterygoid (caudomedially), parabasisphenoid (medially) and square (caudally).

The Iguana iguana's bones were corroborated with the descriptions of Estes et al.
(1988) and Cope (1892), in Squamate order, and Williston (1925) with different reptiles of Lacertilia suborder The first authors mention that pterygoids doesn't participate in the formation bony palate and ectopterygoids articulate with the palatine. Cope (1892) and Williston (1925) observed the presence of small dental alveoli in pterygoid, using their observations in Lacertilia suborder and Squamate order. Williston (1925) compared ectopterygoid homologous to a process pterygoid, in mammal. All authors stated that epipterygoid was present. The squares (Figure 2:13) have morphology that resembles a square, they are convex, and its lateral edge has a concavity and a crest, the tympanic crest, in addiction it articulates the coronoid'mandible, squamosal (dorsally), supratemporal (dorsomedially) and pterygoid (ventromedially). This research was been supported by Cope (1892), but discordant of results found by Williston (1925) considered the square fused to jugal .

The prootics (Figure 2:12) form the laterals walls of neurocranium, they articulate with the supraoccipitals (dorsomedially) exoccipital (caudally) basioccipital (ventrocaudally) and basisphenoid (ventromedially). Williston (1925) had confirmed the findings of this study. In the melting process, of birds and domestic animals, the prootic and supratemporal was fused, forming temporal. Such a combination was been noted in the pterygoid and occipital, these phenomens reflected the evolutionary development of species. This phenomen also occurred with prefrontals, postorbitals, postfrontals and squares (KARDONG, 2011).

The mandible are made of seven: dentary, splenial, coronoid, angle, surangle, prearticular and articular, (Figure 3). Dentary (Figure 3:1) is the most rostral mandible and extends to apex of coronoid. It is only of the mandible has teeth cavities, and its labial face, rostrally, it observes five foramen mentuals and a fissure. Dentary articulates coronoid (caudodorsally), splenial (caudomedially), angle (ventrocaudally). Splenial (Fig. 3:4) localized on lingual surface (caudoventrally the teeth cavities) and the buccal face (ventrally surangle), as well as it articulates with dentary (rostrally), angle (ventrally), prearticular (caudally) and coronoid (dorsally). In union with dentary, in lingual face, observe a foramen, rostroventral alveoly foramen, next to this foramen, in splenial, note two foramens, a rostral, rostral milohioide foramen, and other caudal, caudal milohioide foramen. 


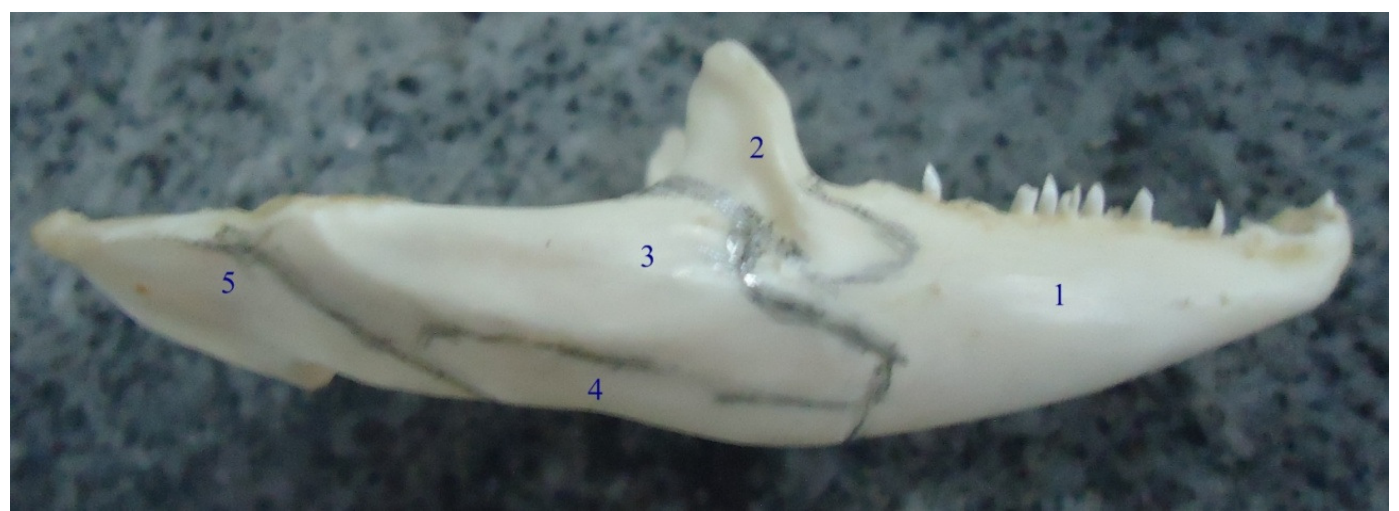

Figure 3. Lateral view mandible Iguana iguana. 1-dentary, 2-coronoid , 3-surangle bone, 4-splenial , 5prearticular .

The coronoid (Figure 3:2) situated between dentary and surangle in face labial, it has three processes: a large dorsal process, coronoid eminence that articulates with pterygoid and ectopterygoid a ventral process, in lateral aspect, vestibular process and another on the medial side, labial process. The angle is located on ventral surface mandible was articulated, in lingual surface, splenial (rostrodorsally), prearticular (caudodorsally) and in labial face, dentary (rostrally) surangle (caudally).

The surangle (Figure 3:3) forms the more dorsocaudal part of mandible, it localizes rostral coronoid articular facet and it protrudes rostrally level of vestibular process. The prearticular (Figure 3:5) forms ventromedial portion and caudal end of mandible, moreover it has two processes: retroarticular and angular. The retroarticular process is triangular and extends caudally and the angular process localized medially and its morphology resembles a sailboat and in lingual face, there is a extend fosse. The articular situated in dorsocaudal surface mandible, it has discrete condyles, in dorsal face, that connecte square. It articulates with, medially and dorsocaudally, prearticular as well as rostrolaterally surangular. The results in relation to bones involved in formation of mandible Iguana iguana were corroborated for descriptions by Cope (1892); Williston (1925); Estes et al. (1988); Kardong (2011).

In ventral view, there are premaxillary, vomer, palatine, maxillary, pterygoid, ectopterygoid, parasphenoid rostral and parabasisphenoid bones (Figure 4).

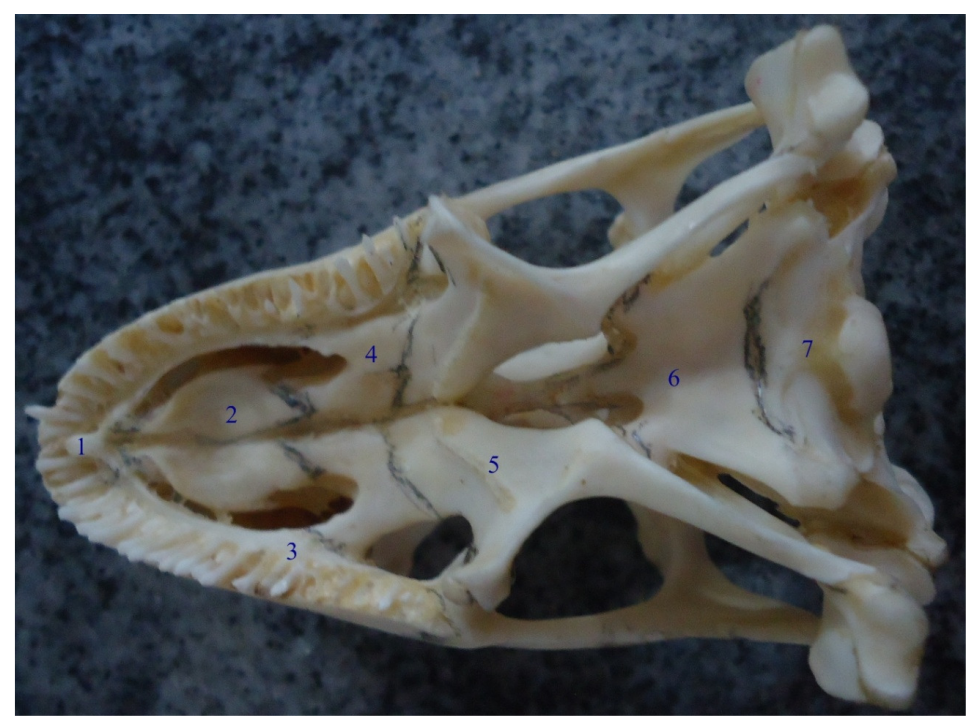

Figure 4. Ventral view skull of Iguana iguana. 1-premaxillary , 2-vomer , 3- maxillary , 4-palatine , 5pterygoid , 6-parabasisphenoid rostral and parabasisphenoid, 8-basioccipital .

The palatines (Figure 4:4) articulate with vomer (rostrally), maxillary (laterally) and pterygoid (caudally), in addiction they have three processes: vomeriane (rostrally), maxillary (laterally) and pterygoid (caudally). In region maxillary process, it localized infraorbital foramen as well as they constitute the caudomedial wall of incisive and palate fissures, they participates in formation medial 
part wall of suborbital foramen. The results about palatines were consistent with Cope (1892), and Estes et al. (1988), but had disagreements in relation Williston (1925) found, in some members Squamate order dental alveoli in palatine.

The basisphenoid is only, and it is fused with parabasisphenoid rostral, it forms ventral part wall of cranial cavity as well as it articulates with pterygoid laterally and basioccipital caudally.
Williston (1925) corroborated iInformations this investigation about basisphenoid and parabasisphenoid rostral of Iguana iguana. Estes et al. (1988) mentioned the basisphenoid was fused with prootic .

Caudal view found the bones: parietal, squamosal, supratemporal, exoccipital-opistotic, supraoccipital, square, pterygoid (Figure 5).

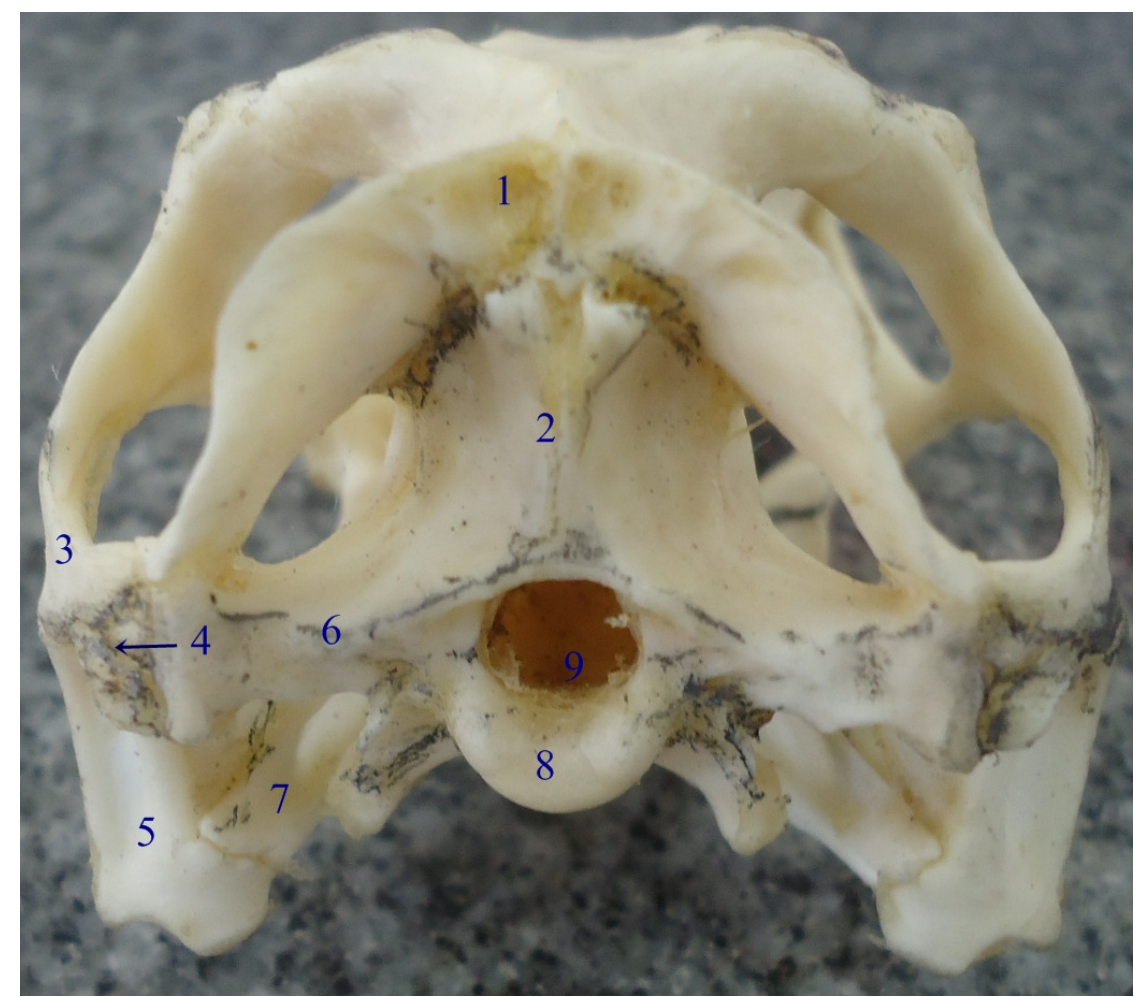

Figure 5. Caudal view skull of Iguana iguana. 1-parietal , 2-supraoccipital , 3-squamosal , 4-supratemporal, 5square, 6-exoccipital-opistotic, 7-pterygoid, 8-condyle occipital , 9-magnum foramen.

The supratemporals (Figure 5:4) are small of triangular morphology, moreover they articulate with square (ventrally), squamosal (laterodorsally), parietal (dorsally) and exoccipital (medially). The description supratemporal in Iguana iguana differ regarding the observations of Williston (1925) in nomenclature, he called supratemporal as tabular and according to author, and it can be absent. Estes et al. (1988) also used the tabular and supratemporal was considered as processparietal.

The supraoccipital (Figure 5:2) constitutes dorsal part magnum foramen it also articulates with parietal (dorsally as well as laterally), exoccipitalopistotic (ventrally) and prootic (rostrally). The basioccipital (Figure 5:8) forms caudal floor of braincase, moreover participates of formation medial part of occipital condyles, it also articulates with the exoccipital (dorsolaterally), prootic (rostrolaterally) and parabasisphenoid rostral. The exoccipital-opistotic (Figure 5:6) are agglutinated and form caudal wall of skull, and side edges of magnum foramen., it articulates supraoccipital (dorsomedially), prootic (rostrally) and basioccipital (ventromedially). It has two developed crests laterally: interfenestraland tuberal crests. Estes et al. (1988) corroborated thedescriptions this research for exoccipital-opistotic in relation to its merger. For them these bones fused in embryonic period and early growth stages. Cope (1892) cited that occipital condyle consisted of portions basioccipital and exoccipital. Williston (1925) cited that supraoccipital was singular, but exoccipital and paraoccipital were bilaterals. In addition, according to this author, occipital condyles were made only exoccipitais. The paraoccipitalis were been fused to the supraoccipital, in fetal life. 


\section{CONCLUSION}

The skull bones of Iguana iguana have characteristics that are similar to other representatives of Reptila Order. However, the presence of two vomers bone has been describe, what makes them unique in that order.

RESUMO: As iguanas (Iguana iguana) são animais que podem atingir até $110 \mathrm{~cm}$ de comprimento. Estes animais são reconhecidos pela crista de espinhos que percorre toda a extensão das costas. Vivem na Amazônia, Cerrado e Caatinga, desde o México até o Brasil Central, e são arborícolas, de hábito diurno e são herbívoros. Os répteis conquistaram o ambiente terrestre, após adquirir a capacidade de evitar a desidratação, a fecundação interna e seu ovo possuir casca. Este grupo ocupa todos os habitats, exceto as regiões polares. Objetivou-se a descrição dos ossos do crânio de um exemplar desta espécie. O animai foi doado, após morte por traumatismo, pela Companhia Independente de Polícia Rodoviária e Ambiental do Estado do Tocantins (CIPRA) ao Laboratório de Anatomia Veterinária do Curso de Medicina Veterinária da Universidade Federal do Tocantins, Campus de Araguaína. Macerou-se todo o animal pela técnica de cocção. O crânio foi separado e em seguida ossos que o constituíam foram descritos. O crânio da Iguana iguana era constituído pelos seguintes ossos: pré-maxilar, nasal, pré-frontal, frontal, pós-frontal, parietal, maxilar, lacrimal, jugal, pósorbital, esquamosal, ectopterigoide, epipterigoide, pterigoide, pró-ótico, quadrado, mandíbula, vômer, palatino, paraesfenoide rostral, parabasiesfenoide, supratemporal, exo-occipital-opistótico, supraoccipital. Os ossos do crânio do iguana possuem semelhança com os ossos do crânio dos outros representantes dos répteis.

PALAVRAS-CHAVE: Anatomia. Animais silvestres. Descrição. Iguanídeos. Répteis.

\section{REFERENCES}

COPE, E. D. The osteology of the Lacertilia. Proceedings American Philosophical Society, Philadelphia, v. 30, p. 185-222, 1892.

CUBAS, Z. S.; SILVA, J. C. R.; CATÃO-DIAS, J. L. Tratado de Animais Selvagens. São Paulo: Roca, 2007. $1354 \mathrm{p}$.

ESTES, R.; QUEIROZ, K.; GAUTHIER, J. Phylogenetic relationships within Squamata. In: ESTES, R.; PREGILL, G. (Ed). Phylogenetic relationships of the lizard families. Stanford: Essays commemorating Charles Lews Camp, 1988. p. 119-281.

HILDEBRAND, M.; GOSLOW, G. J. Análise da estrutura dos Vertebrados. 2. ed. São Paulo: Atheneu, 2006. $700 \mathrm{p}$.

KARDONG, K. Vertebrados - Anatomia Comparada, Função e Evolução. 5. ed. São Paulo: Roca, 2011. $913 \mathrm{p}$.

QUEIROZ, K. Phylogenetic Systematics of Iguanine Lizards - A Comparative Osteological Study. Zoology, University of California, California, v. 118, p. 1-203, 1987. http://dx.doi.org/10.5962/bhl.title.4857

RODRIGUES, H. Técnicas Anatômicas. 4. ed. Vitória: GM - Gráfica e Editora, 2010. 269 p.

WIELOCH, D. R.; VEADO, B. V.; FURTADO, D. B. Cadernos da Fundação Zoo-Botânica I - animais de zoológico. Fundação Zoo-Botânica de Belo Horizonte, Belo Horizonte, 1977. 236 p.

WILLISTON, S. W. The osteology of the reptiles. Harvard University Press, Cambridge, 1925. 300 p. 